\title{
材料教育
}

\section{高等学校理科教科指導に打ける 特異材料を用いた付加価值付与}

\author{
仲野 純 章* 木 村 久道**
}

\section{1. は じめに}

高等学校教育の現場は「探求的な学習」が拡充されて大き く変わりつつある. 探求的な学習とは, 学生が主体的に課題 を設定し, 教科横断的な視点から, 問題解決的な活動が発展 的に繰り返されていく一連の学習方法である.このような流 れの中，科学技術系人材の育成を目的としたスーパーサイエ ンスハイスクール $(\mathrm{SSH})$ に全国の約 200 校が指定されてお り, 既に各校独自のカリキュラムで様々な探求的活動が進め られている. そのうちの一校である奈良高等学校において も, 科学のトップランナーを育成すべく様々な探求的活動が 展開されている(1). 特に, 理科系の中に設けられた SSH コ 一スに颃いては, 第 2 学年からの 2 年間をかけて課題研究 を展開できるカリキュラムになって抢り, 得られた研究成果 の一部は学外に向けて公開されている(2)-(4). 学生にとっ て，こうした一連の活動は個人では成し難く，学校という集 団・組織に身を置いて活動するからこそ享受できる，いわば 学校教育における付加価值の一つといえる. 最近, 各教科指 導において，いわゆるアクティブラーニングを意識した授業 がなされるようになってきたが，依然として，知識伝達型の 教科書の内容に沿った教科指導が多い.このような探求的な 学習拡大の流れ, さらには, 昨今声高に叫ばれている高大接 続の議論 ${ }^{(5)}$ を考えると, 教科指導の中身も同時に変えていか なくてはいけないのではと強く感じる. 高等学校段階での探 求活動や高等教育以降の学びや研究の土台となるものは, 紛 れもなく教科指導の内容であるからである. そのため, 高等 学校段階での探求活動や高等教育以降の学びや研究をよりス ムーズにハイパフォーマンスなものにするとなれば, 土台と
なる教科指導の内容もその先を見据えたものにしていかねば ならない. なお, 新しい時代にふさわしい高等学校教育を提 言・検討するために設けられた「文部科学省 高大接続シス テム改革会議」では, 各教科で求められる能力が具体的に検 討されている. 理科(物理)に関しては, 図1に示すように, 「特に重視すべき思考力・判断力・表現力等のイメージ例」(6) として,

・自然事象の中に問題を見出し, 観察・実験のための予想や 仮説を立てる力

・予想や仮説を確かめる観察・実験を計画・実施する力 などが挙げられている.しかし, 本質的で広がりを持った知 識がない中では, これらの思考力・判断力・表現力を小さく 限定しかねない.

こうした状況の中，「敢えて学校で教科を学ぶ意味」は何 かと考えたとき, 教科指導の中にもやはり, 学校だから体 験・習得・思考できたという付加価值があるべきであると考 えている.

O自然事象の中に問題を見出し、観察・実験のための予想や仮説を立てる力 ○予想や仮説を確かめる観察・実験を計画・実施する力

○観察・実験デー夕を分析・解釈する力

(例) ·結果についてモデルを使つて考察し、表やグラフで表現する力 ○要因の抽出や観察・実駼結果について推論する力

(例) ・事象の変化に及ぼす要因を推論によって推測し、結果を予測する力 ・锶察・実験結果を帰納的に推論して規則性や共通性を導く力

○報告書の作成・発表・討論などを通じて表現する力

図 1 理科(物理)において特に重視すべき思考力・判断 力・表現力等のイメージ例 (文部科学省高大接続 システム改革会議資料) ${ }^{(6)}$.

* 奈良県立奈良高等学校 $;$ 教諭 ( $7630-8113$ 奈良市法蓮町836)

** 元 東北大学金属材料研究所; 准教授

Imparting Additional Value to Subject Instruction on Science at High Schools Using Unique Substances; Sumiaki Nakano* and Hisamichi Kimura** (*Nara High School, Nara. **Tohoku University, Sendai (former))

Keywords: physics education, metallic glass, educational tool, spring characteristic, strain 2017年 3 月14日受理[doi:10.2320/materia.56.389] 


\section{2. 特異材料活用がもたらす可能性の検討}

教科指導の中における付加価值付与の一つのアプローチと して，我々は，鉄やアルミニウムといった身近な材料とは異 なる性質を持つ特異材料を用いて, 科学に対する興味関心と 深い学びを促す可能性に着目してきた。こうした特異材料の 一つとしては，特徵的な構造と物性を持つ「金属ガラス」が 挙げられ，我々は物質の状態変化に関する学習の中でそれを 取り上げる試反も行ってきた(7)、金属ガラスはランダムな原 子配列を持つアモルファス金属の一種であるが， $50 \mathrm{~K}$ 以上 の広い過冷却液体域を持ち, 2 桁以上の遅い冷却速度でも作 製できる点が通常のアモルファス金属との大きな違いであ る.この金属ガラスは, 引張強度が $1 \sim 4 \mathrm{GPa}$ と高強度であ り，一方で，優れた勒性も備えている。 また，歪みに対して 破断まで弾性的に変形し, 大きな弾性限(比例限) 打よび弾性 エネルギーがあり, 耐疲労特性にも優れる ${ }^{(8)(9)}$. 今回, 力学 分野で扱う「ばね」を題材にしたとき，こうした金属ガラス を用いた場合に例えばどのような活動の広がりと学びの掘り 下げができ得るものかを考えてみたい.

\section{3.「金属ガラス」の特徵を活かし，ばねを見つめ直す}

\section{（1）金属ガラス活用のメリット}

強度・勒性・耐疲労特性等の面で一般の金属より優れた機 械的特性を持つ金属ガラスは，圧縮加工を施してのばね成形 と、このばねを用いた力学的評価に適しているといえる。 た，金属ガラスを活用するもう一つのメリットとして，金属 ガラスという特異材料を使用しているという特別感が学生の 科学的興味をくすぐり, 大学等研究機関の「空気」を感じる ことができるということも挙げられる。こうしたメリットを 活かし, 以下の実験を行った。

\section{(2) 方法}

上述した金属ガラスの機械的特性を活かし，以下のような 折り曲げ成形式の各種ばねを作製した，数百種類以上の金属 ガラスがある中，今回は比較的作製しやすい $\mathrm{Zr}_{55} \mathrm{Cu}_{30} \mathrm{Al}_{10}$ $\mathrm{Ni}_{5}$ 金属ガラス ${ }^{(10)}$ を選択した。液体急冷法により作製され た $\mathrm{Zr}_{55} \mathrm{Cu}_{30} \mathrm{Al}_{10} \mathrm{Ni}_{5}$ 金属ガラス薄帯から, 幅 $3 \mathrm{~mm}$ の短冊形 状を 6 本切り出し(長さ: $24,34,44,54,64,74 \mathrm{~mm}$ ), 両端 から $2 \mathrm{~mm}$ の 2 箇所に切欠きを形成した。そして，切欠き とその直近の折り曲げ位置との距離，及び隣り合う折り曲げ 位置の距離がいずれも $10 \mathrm{~mm}$ になるよう手作業による圧縮 加工を施し，図 $2(\mathrm{a})$ から (f) のように折り曲げ回数の異なる ばねを成形した，各切欠きには糸製のフックを括りつけ，図 3(a)から (f)のように，一方の系製フックでばねをつり下 げ，他方の采製フックに質量が $10,20,30,40 \mathrm{~g}$ のおもりを順 に付加して荷重一伸び特性を測定した。ここで，それぞれの ばねには系製フックとの接合点(荷重支点)が 2 箇所存在す るが, 荷重支点間距離の初期值からの変化量を伸び量と定義 した.

\section{(3) 結果}

奇数回折りの場合の荷重一伸び特性を図 4 に, 偶数回折り の場合の荷重一伸び特性を図 5 に示す. 1 回折りの(a)形状の 場合，伸びの值は荷重に比例せず，図 4(a)のように曲線状 のグラフとなった. しかし, 2 回折りの(b) 形状に至ると, グラフ形状は図 5 (b) に示すように直線状となり, 教科書等 でよく目にする「ばねの伸びと弾性力の関係」と類似のグラ フとなった。 ところが， 3 回折りの(c)形状になると, 図 4 (c)のように再び直線性は損なわれた。しかし，4回折りの (d) 形状になると, 図 5(d)に示すように再び直線状となっ た．同様に，5回折りの(e)形状になると，図 $4(\mathrm{e})$ のように

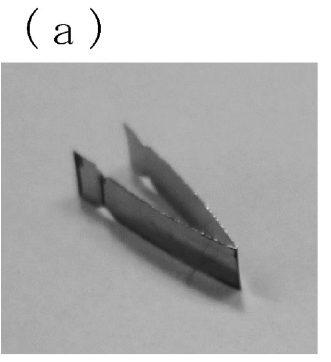

(d)

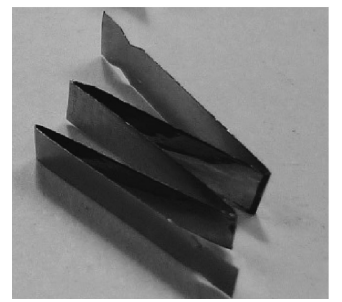

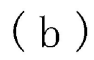

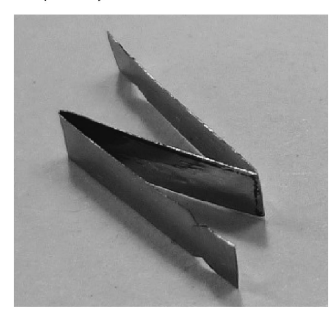

( e )

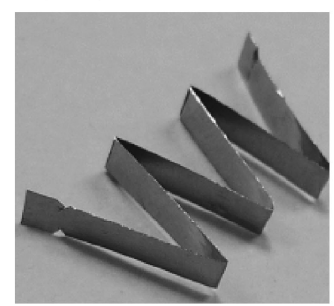

(c)

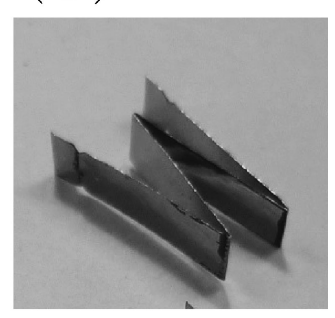

( f )

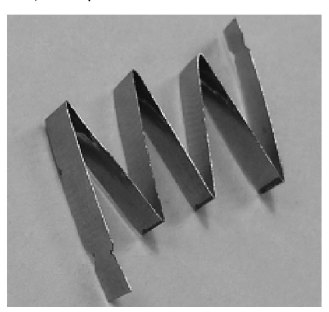

図 2 各種供試ばね; (a) : 1 回折り, (b) : 2 回折り, (c) $: 3$ 回折り, (d) $: 4$ 回折り, (e) $: 5$ 回折り, (f) $: 6$ 回 折り. 


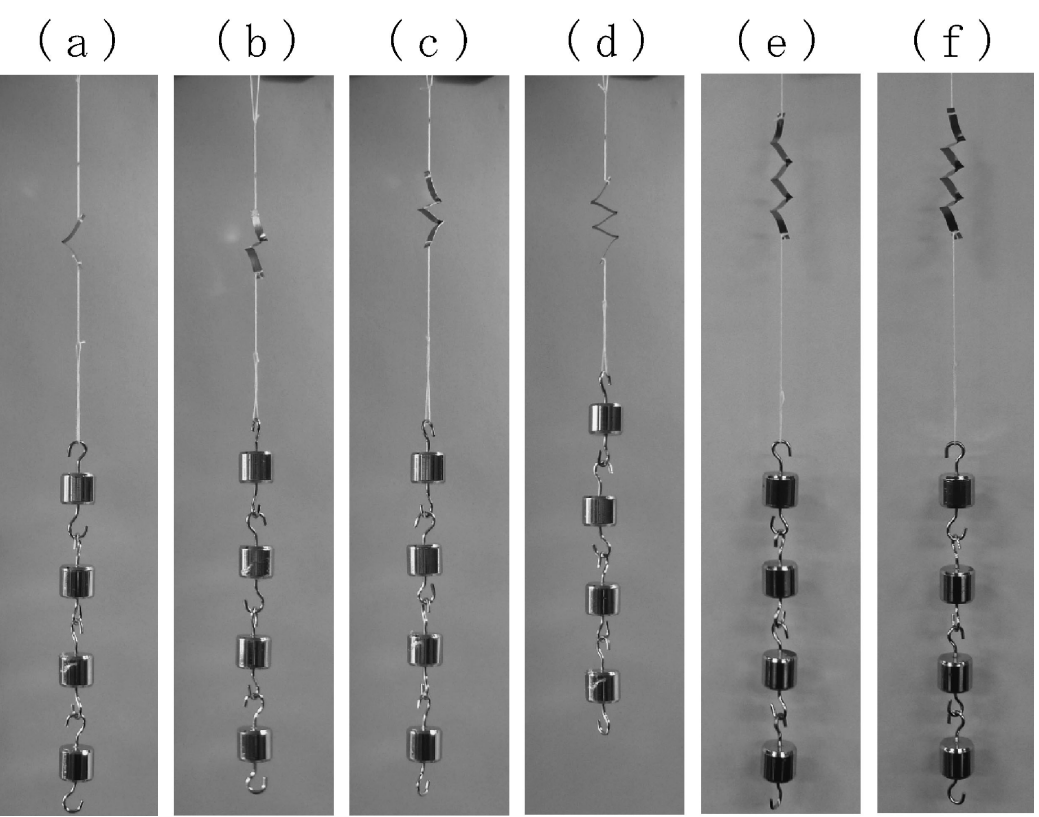

図 3 各種供試ばねに対する荷重一伸び特性の測定風景.

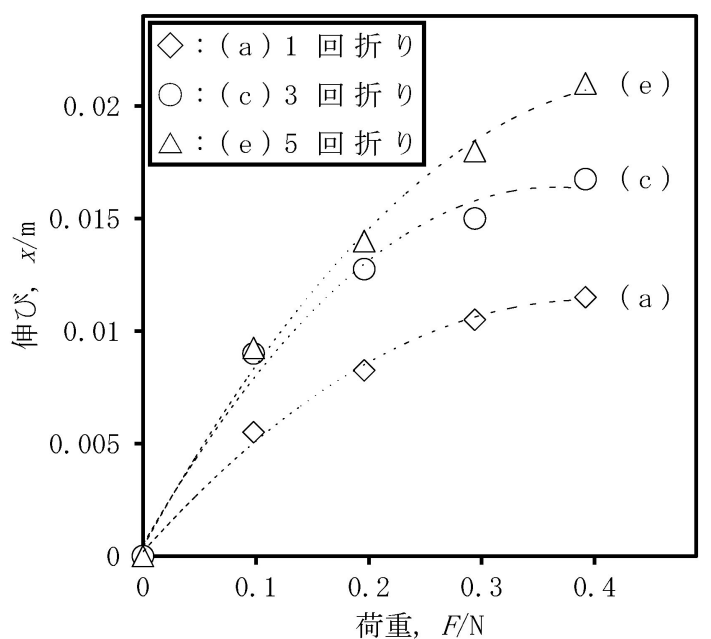

図 4 奇数回折りの場合の荷重-伸び特性.

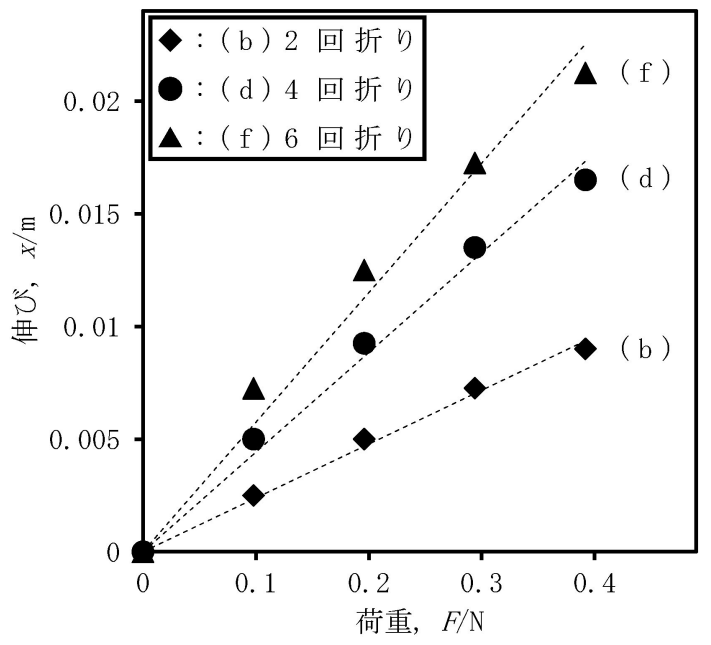

図 5 偶数回折りの場合の荷重-伸び特性. 直線性は損なわれ，6回折りの(f)形状になると, 図 5(f)に 示すように再び直線状に近づいた。このように，折り曲げ回 数により線形ばねと非線形ばねの両方の性質が交互に現れる 結果となった。 また，図 4 に示す 3 種類の奇数回折りのば ねについて比較すると, 曲げ回数の増加とともに見かけの弾 性係数が小さくなるという傾向が見られ，同様の傾向は，図 5 に示す 3 種類の偶数回折りのばねについても見られた.こ のことは, 後述の式 $(1)$ に代表されるような「ばねの長さ が長いほど弾性係数は小さくなる」というばねに見られる一 般的な傾向と合致する.

\section{(4) 学びの掘り下げ}

ばねの弾性は，ミクロな視点で見るとばねを作っている金 属自身の弾性，つまりは金属内の原子構造に起因する。つる 巻きばね全体の話として語られることの多いフックの法則 は，第一には，このようにミクロにみたときの話である。そ して，その原子レベルの積み重ねの結果として，比例限界内 にある金属においては，荷重と伸び(たわみ)の関係には正比 例の関係が現れ，フックの法則が満足される．また，上述の 自作ばねは，いわゆる引張りではなく曲げによる変形を利用 したばねである，引張りでは変形しにくい材料でも，今回の ように変形のさせ方によっては変位が大きく現れる。さら に，変位が拡大されるような二次的構造を与えることで， 「見かけの弾性」をより増大させることができる．馴染みの あるつる巻きばねも，実はこうした変形のさせ方の工夫や二 次的構造で変位を拡大している一例である.つまり，つる巻 きばねを伸ばすとき，ばねの各部分はねじれを起こし，各部 分のねじれが合成されて全体の大きな伸びとなる。なお，つ る巻きばねの伸びに影響する因子は実に様々であり，有効巻 き数を $N \mathrm{a}$ ，コイル中心径を $D$, 材料の横弾性係数を $G$, 直 
径を $d$, とすると，加える力 $F$ とつる巻きばねの伸び $x$ との 間に式 (1) が成立することが知られている(11).

$$
x=\left\{8 \cdot N \mathrm{a} \cdot D^{3} /\left(G \cdot d^{4}\right)\right\} \cdot F
$$

このように，金属自身の弾性やばねの弾性とはどういった ものか，という視点から捉え直すことで，今後，単なるばね に対する考え方も変わるであろう.

\section{4. ばね=フックの法則を満足するつる巻きばね，と} いう短絡的知識で良いのか

高等学校までの教科書の中で出てくるばねは，「フックの 法則を満たすつる巻きばね」一辺倒であろう。しかし，一歩 実社会に出ると，不等ピッチコイルばね，定荷重ぜんまいば ね等，荷重と伸び(たわみ)の関係が正比例にならない非線形 ばねが多くある．本稿で紹介した金属ガラスを用いたばねで は，線形ばねと非線形ばねの両方の性質が現れた。こうした 事例から，学生は学びと実態の間を埋める本質的な学びの必 要性を感じられる。そうして，「そもそもばねとは何なの か」,「フックの法則とはどういうものなのか」を考えるきっ かけが生まれるだろう。

\section{5.おわりに}

高等学校教育における探求活動をより深いものにし，ま た，高等教育以降の活躍をスムーズになるようにと考えたと き, 我々高等学校教員が教科指導でその橋渡しに尽力せね梳 ならないことは明らかである. 教員それぞれのバックグラウ ンドや個性を活かした様々なアプローチがあると思うが，特 異材料を用いたアプローチにも一つの可能性を感じている. 本稿では, 特異材料の例として金属ガラスを挙げ, 力学分野 に抢いてそれを活用する一例を示した。今後も，他機関と連 携しながら, 高等学校にある設備で実現できる特異材料を活 用した理科教育の可能性を追求していきたい.
今回の検討実験に用いた $\mathrm{Zr}_{55} \mathrm{Cu}_{30} \mathrm{Al}_{10} \mathrm{Ni}_{5}$ 金属ガラス薄帯 をご提供頂きました株式会社真壁技研（仙台市宮城野区）の 真壁昌宏様始め，皆様に厚く御礼を申し上げます。

\section{文献}

（1）奈良県立奈良高等学校平成 24 年度指定スーパーサイエンスハ イスクール研究開発実施報告書, 4(2016), 1-82.

（2）榊原颯輝，佐藤克哉，芝脇翔山，薮内智史，吉田尚弘，増田 貴行, 仲野純章 : 奈良県立奈良高等学校平成 28 年度スーパー サイエンスハイスクール生徒研究発表会, (2017), 6-10.

（3）西澤一輝, 西村太一, 松枝蒼弥, 増田貴行, 仲野純章 : 奈良 県立奈良高等学校平成 28 年度スーパーサイエンスハイスクー 儿生徒研究発表会, (2017), 11-14.

（4）上平拓夢，小出翔太，小池もも，脇田愛未，増田貴行，仲野 純章 : 奈良県立奈良高等学校平成 28 年度スーパーサイエンス ハイスクール生徒研究発表会, (2017), 15-18.

( 5 ) 河合塾 : Kawaijuku Guideline, $7 \cdot 8$ (2016), 2-15.

(6) 文部科学省高大接続システム改革会議ホームペーシ (http:// www.mext.go.jp / b_menu / shingi / chousa / shougai / 033 / shiryo/__icsFiles/afieldfile/2015/06/22/1359126_06_1.pdf).

（7）仲野純章, 木村久道: 奈良県高等学校理化学会会報, 56 (2017)，掲載予定.

（8）寺島岳史 : 神奈川大学工学研究所所報, 36 (2013), 22-31.

（9）増本健監修, ウォーク編著：金属何でも小辞典, 講談社, (2009), 199-210.

(10) G. Q. Xie, W. Zhang, D. V. Louzguine, H. M. Kimura and A. Inoue: Mater. Trans., 48(2007), 1589-1594.

(11) M. Kodama: Trans. of JSSR, 3(1955), 74-77.

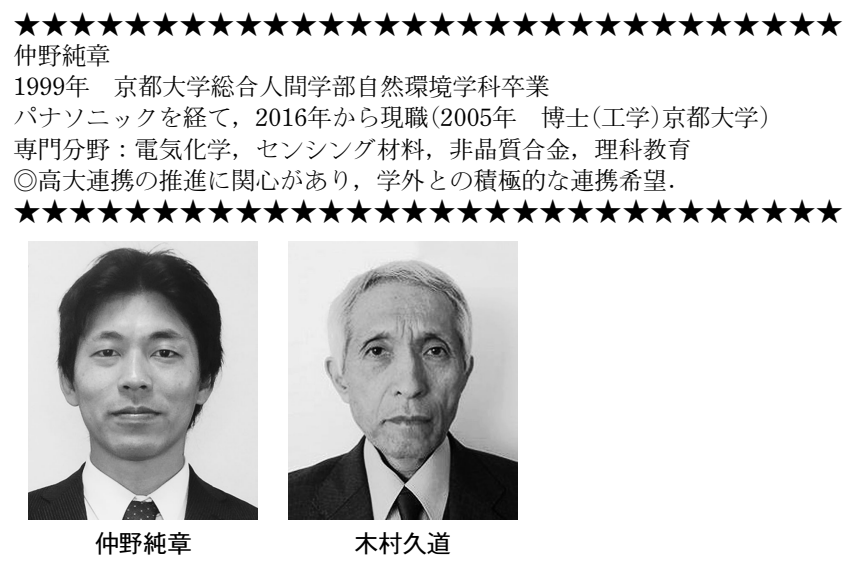

